DR DANIELE DI MASCIO (Orcid ID : 0000-0002-6560-3393)

PROFESSOR GIUSEPPE RIZZO (Orcid ID : 0000-0002-5525-4353)

Article type : Systematic review

\title{
Diagnostic accuracy of prenatal ultrasound in identifying the level of the lesion in fetuses with open spina bifida: a systematic review and meta-analysis
}

Daniele Di Mascio ${ }^{1 *}$, Francesca Greco ${ }^{2 *}$, Giuseppe Rizzo ${ }^{3,4}$, Asma Khali1 ${ }^{5,6}$, Danilo Buca ${ }^{7}$, Felice Sorrentino $^{2}$, Lorenzo Vasciaveo ${ }^{2}$, Pantaleo Greco $^{8}$, Luigi Nappi $^{1}$, Francesco D’Antonio ${ }^{7}$

*Daniele Di Mascio and Francesca Greco share first authorship

1: Department of Maternal and Child Health and Urological Sciences, Sapienza University of Rome, Rome, Italy

2: Fetal Medicine Unit, Department of Obstetrics and Gynecology, University of Foggia, Italy

3: Division of Maternal and Fetal Medicine, Ospedale Cristo Re, University of Rome Tor Vergata, Rome, Italy

4: Department of Obstetrics and Gynecology, The First I.M. Sechenov Moscow State Medical University, Moscow, Russia

5: Fetal Medicine Unit, Saint George's Hospital, London, UK

6: Vascular Biology Research Centre, Molecular and Clinical Sciences Research Institute, St George's University of London, London, UK

7: Center for Fetal Care and High-risk Pregnancy, Department of Obstetrics and Gynecology, University of Chieti, Chieti, Italy

This article has been accepted for publication and undergone full peer review but has not been through the copyediting, typesetting, pagination and proofreading process, which may lead to differences between this version and the Version of Record. Please cite this article as doi: 10.1111/AOGS.14001

This article is protected by copyright. All rights reserved 
8: Department of Morphology, Surgery and Experimental Medicine, Section of Obstetrics and Gynecology, University of Ferrara, S. Anna University Hospital, Cona, Ferrara, Italy.

\section{Corresponding Author:}

Francesco D'Antonio

Center for Fetal Care and High-risk Pregnancy, Department of Obstetrics and Gynecology, University of Chieti, Chieti, Italy

Email: dantoniofra@gmail.com

\section{Conflicts of interest:}

None

This article is protected by copyright. All rights reserved 


\section{ABSTRACT}

Introduction: The role of prenatal ultrasound in correctly identifying the level of the lesion in fetuses with open spina bifida has yet to be determined. The primary aim of this systematic review was to report the diagnostic accuracy of ultrasound in determining the level of the lesion in fetuses with open spina bifida. The secondary aim was to elucidate whether prenatal magnetic resonance imaging (MRI) improves the diagnostic performance of prenatal imaging in correctly identifying the level of the lesion. Material and methods: Inclusion criteria were studies reporting the agreement between ultrasound, MRI and postnatal or post-mortem assessment of fetuses with spina bifida. Agreement was defined as: complete (when the upper level of the lesion detected prenatally was the same recorded at postnatal or post-mortem evaluation), within one (when the upper level of the lesion recorded prenatally was within one vertebral body higher or lower than that reported postnatally) and within two vertebral bodies (when the upper level of the lesion recorded prenatally was within two vertebral bodies higher or lower than that reported postnatally or postmortem evaluation). Meta-analyses of proportions were used to combine data. Results: Fourteen studies (655 fetuses) were included. Ultrasound was able to identify the correct level of the lesion in $40.9 \%$ (95\% CI 26.9-55.6) of cases. The upper level of the lesion recorded on ultrasound was within one vertebral body in 76.2\% (95\% CI 65.0-85.9) of cases, while within two segments in 92.4\% (95\% CI 84.3-97.7). Fetal MRI detected the exact level of the lesion in $42.5 \%$ (95\% CI 35.9-45.2) of cases; the level of the lesion recorded on MRI was higher in $26.4 \%$ (95\% CI 20.0-33.3) of cases and lower in $32.4 \%$ (95\% CI 25.5-39.7) than that confirmed postnatally. The upper level of the lesion recorded on MRI was within one vertebral body in $76.2 \%$ (95\% CI 65.9-85.2) of cases, while within two segments in 94.2\% (95\% CI 90.2-97.2).

Conclusions: Both ultrasound and MRI have a moderate diagnostic accuracy in identify the upper level of the lesion in fetuses with open spina bifida.

\section{Keywords:}

spina bifida, myelomeningocele, ultrasound, magnetic resonance imaging, MRI, diagnostic acuracy

\section{Abbreviations}


MRI magnetic resonance imaging

\section{Key message:}

Both ultrasound and magnetic resonance imaging have a moderate diagnostic accuracy in correctly identifying the anatomical level of the lesion in fetuses with open spina bifida. 


\section{INTRODUCTION}

Spina bifida is among the most common congenital anomalies identified prenatally with a reported prevalence of around 0.5 per 1000 births. It is caused by an incomplete closure of the neural tube during embryonic life which leads to formation of a cleft in the vertebral column, with a corresponding defect in the skin so that the meninges and spinal cord are exposed. Spina bifida is also known as "open spinal dysraphism" or "spina bifida aperta" when the neural tissue is exposed, as opposed to "closed spinal dysraphism" or "spina bifida", when the cleft in the vertebral column is not associated with a corresponding epithelial defect and the neural tissue is not exposed. ${ }^{1-3}$

Prenatal diagnosis of spina bifida is fundamental as it allows referring these fetuses to centers with high expertise in surgical treatment of this conditions, and it also fundamental for an accurate prenatal counselling. Recently, the advances in prenatal imaging have led to significant improvement in the diagnostic accuracy of ultrasound in identifying these anomalies, with a reported detection rate of about $90 \%$ either by direct visualization of the spinal defect or the detection of the associated intra-cranial findings such as the lemon and banana signs., ${ }^{2,4-6}$ Conversely, the diagnostic accuracy of ultrasound has been reported to be relatively poor for closed spinal defect mainly as the consequence of the lack of associated intracranial signs. ${ }^{2}$ Prenatal diagnosis of open spina bifida is commonly accomplished during the second trimester of pregnancy, at the time of the anomaly scan, although first trimester diagnosis is widely reported in the published literature. . $^{3,7}$

Accurate identification of the level of the lesion in fetuses with spina bifida represents another fundamental issue also when assessing candidacy for open fetal surgery, while might potentially be of less importance for fetoscopic repair, although this technique has not been validated in large randomized controlled trials yet. ${ }^{8,9}$

Despite this, the role of prenatal ultrasound in correctly identifying the level of the lesion in fetuses with open spina bifida has yet to be determined. Fetal magnetic resonance imaging (MRI) has been reported to provide additional information in fetuses with brain anomalies not detected on ultrasound and is commonly performed to confirm the diagnosis, to rule out any additional malformations, and predict the prognosis. ${ }^{10-11}$ However, it is not known whether MRI truly improves the diagnostic accuracy of ultrasound in correctly identifying the level of the lesion in fetuses with open spina bifida and whether this should be routinely performed in such cases. 
The aim of this systematic review was to explore the diagnostic performance of prenatal ultrasound and MRI in determining the level of the lesion in fetuses with open spina bifida.

\section{MATERIAL AND METHODS}

\section{Protocol, eligibility criteria, information sources and search}

This review was performed according to an a-priori designed protocol and recommended for systematic reviews and meta-analysis. ${ }^{13}$ Medline and Embase databases were searched electronically on January 2020 utilizing combinations of the relevant medical subject heading (MeSH) terms, key words, and word variants for "spina bifida", "neural tube defects", "ultrasound" and "magnetic resonance imaging". The search and selection criteria were restricted to English language. Reference lists of relevant articles and reviews were hand searched for additional reports. Prisma guidelines were followed. ${ }^{14-15}$

\section{Outcomes explored, study selection, data collection and data items}

The primary aim of the study was to elucidate the diagnostic accuracy of prenatal ultrasound (either 2D or 3D) in correctly identifying the level of the lesion in fetuses with open spina bifida. The reference standard was postnatal assessment either by imaging techniques (X-ray or MRI) or findings at autopsy (post-mortem assessment).

For the purpose of the analysis, agreement between ultrasound and post-natal or post-mortem assessment was defined as:

- Complete, when the upper level of the lesion on ultrasound was the same recorded at postnatal or post-mortem evaluation.

- Within one vertebral body, when the upper level of the lesion recorded on ultrasound was within one vertebral body higher or lower than that reported postnatally.

- Within two vertebral bodies, when the upper level of the lesion recorded on ultrasound was within two vertebral bodies higher or lower than that reported postnatally.

Furthermore, we explore the discrepancy between the level of the lesion recorded on ultrasound and that confirmed postnatally (1,2,3 or $\geq 4$ vertebral bodies respectively). Sub-group analyses 
according to the type of ultrasound technique adopted (2D or 3D) and the time of ultrasound assessment (including only studies from the last decade) were also performed.

The secondary aim was to elucidate the diagnostic accuracy of fetal MRI in correctly identifying the level of the lesion in fetuses with open spina bifida.

Only studies reporting the diagnostic accuracy of either ultrasound or MRI in detecting the level of the lesion in fetuses with open spina bifida were considered suitable for the inclusion in the current systematic review. Postnatal studies or studies from which cases diagnosed prenatally could not be extracted were excluded. Paediatric and surgical series including only symptomatic cases or patients undergoing surgical treatment not reporting information on the observed outcomes were also excluded. Studies of published before 2000 were also excluded, as we considered that advances in prenatal imaging techniques, improvements in the diagnosis and definition of this anomaly make these less relevant.

Only full text articles were considered eligible for the inclusion; case reports, conference abstracts and case series with fewer than 5 cases of spina bifida were also excluded in order to avoid publication bias.

Two authors (FG, FDA) reviewed all abstracts independently. Agreement regarding potential relevance was reached by consensus. Full text copies of those papers were obtained, and the same two reviewers independently extracted relevant data regarding study characteristics and pregnancy outcome. Inconsistencies were discussed by the reviewers and consensus reached or by discussion with a third author. If more than one study was published for the same cohort with identical endpoints, the report containing the most comprehensive information on the population was included to avoid overlapping populations.

\section{Quality assessment and risk of bias}

Quality assessment of the included studies was performed using the Newcastle-Ottawa Scale (NOS) for cohort studies. According to NOS, each study is judged on three broad perspectives: the selection of the study groups; the comparability of the groups; and the ascertainment outcome of interest.${ }^{16}$ Assessment of the selection of a study includes the evaluation of the representativeness of the exposed cohort, selection of the non-exposed cohort, ascertainment of exposure and the demonstration that outcome of interest was not present at start of study. Assessment of the comparability of the study includes the evaluation of the comparability of cohorts on the basis of the design or analysis. Finally, the ascertainment of the outcome of interest includes the evaluation 
of the type of the assessment of the outcome of interest, length and adequacy of followup (Wells). ${ }^{16}$ According to NOS a study can be awarded a maximum of one star for each numbered item within the Selection and Outcome categories. A maximum of two stars can be given for Comparability. ${ }^{16}$

\section{Statistical analyses}

We used meta-analyses of proportions were used to combine data. Funnel plots displaying the outcome rate from individual studies versus their precision (1/standard error) were carried out with an exploratory aim. Tests for funnel plot asymmetry were not used when the total number of publications included for each outcome was less than ten. In this case, the power of the tests is too low to distinguish chance from real asymmetry. Between-study heterogeneity was explored using the $\mathrm{I}^{2}$ statistic, which represents the percentage of between-study variation that is due to heterogeneity rather than chance. A value of $0 \%$ indicates no observed heterogeneity, whereas $\mathrm{I}^{2}$ values of $\geq 50 \%$ indicate a substantial level of heterogeneity. ${ }^{17-20}$ All analyses were performed using Stata version 13.1 (Stata Corp., College Station, TX, USA).

\section{RESULTS}

\section{Study selection and characteristics}

243 articles were identified, 61 were assessed with respect to their eligibility for inclusion and 14 studies including 655 fetuses affected by spina bifida were included in the systematic review (Table 1, Supporting Information Tables S1-S2, Figure 1). ${ }^{21-34}$

The results of the quality assessment of the included studies using NOS are presented in Table 2. Most of the included studies showed an overall good score regarding the selection and comparability of the study groups, and for ascertainment of the outcome of interest. The main weaknesses of these studies were their retrospective design, small sample size, heterogeneity of in gestational age at assessment, protocols for antenatal detection of the level of the lesion and ultrasound technique adopted.

\section{Synthesis of the results}

Ultrasound 
$\operatorname{Ten}^{23-32}$ (452 fetuses) reported the accuracy of ultrasound in identifying the level of the lesion in fetuses with open spina bifida. Overall, ultrasound was able to identify the correct level of the lesion in 40.9\% (95\% CI 26.9-55.6;193/452 fetuses) of cases; in 31.7\% (95\% CI 11.9-55.8; $57 / 233$ ) the level of the lesion recorded on ultrasound was higher, while in $25.7 \%$ (95\% CI 10.5 $44.8 ; 81 / 233$ ) lower than that recorded after birth or at autopsy (Table 3 ).

The upper level of the lesion recorded on ultrasound was within one vertebral body in $76.2 \%$ (95\% CI $65.0-85.9 ; 359 / 468)$, while within two segments in $92.4 \%$ (95\% CI 84.3-97.7; 397/434) of cases.

The discrepancy between the upper level of the lesion detected on ultrasound and that at postnatal assessment or autopsy was one vertebral body in $34.3 \%$ (95\% CI 25.2-43.9; 155/434) of cases, while the corresponding figures for two, three and $\geq$ four vertebral bodies were $20.5 \%$ (95\% CI $8.2-36.6 ; 90 / 467), 4.3 \%$ (95\% CI 1.4-8.7; 22/467) and 2.4\% (95\% CI 0.03-6.2; 8/173) respectively (Table 3 ).

Sub-group analyses according to the type of ultrasound technique adopted (2D or 3D) are reported in Tables 4 and 5. Overall, 2D ultrasound correctly identifying the upper level of the lesion in $36.0 \%$ (95\% CI 24.0-49.0; 155/404), while the agreement was within one in $71.8 \%$ (95\% CI 63.8-79.2; 311/420) and within two vertebral bodies in 90.7\% (95\% CI 81.6-97.0). The level of the lesion recorded on ultrasound was higher in $36.2 \%$ (95\% CI 12.0-64.9; 52/185) and lower in $29.1 \%(95 \%$ CI $12.5-49.0)$ than that confirmed postnatally or postmortem (Table 4).

Only three studies $23,25,32$ (157 fetuses) explored the diagnostic accuracy of 3D ultrasound in identifying the level of the lesion in fetuses with open spina bifida. There was a complete agreement between 3D ultrasound and postnatal assessment in 67.1\% (95\% CI 43.7-86.7; 95/157) of cases, while the discrepancy between pre and postnatal assessment was within one vertebral body in $94.6 \%$ (95\% CI 75.4-99.8; 139/157) and within two in 96.2\% (95\% CI 85.3-99.9) (Table 5).

Finally, when considering only studies published in the last decade, there was complete agreement between the upper level of the lesion described on ultrasound and postnatal or postmortem assessment in $43.7 \%$ (95\% CI 25.0-63.3; 147/302) of cases, while the agreement was within one and two vertebral bodies in 78.9\% (95\% CI 58.8-93.5; 194/250) and 51.3\% (95\% CI $34.5-67.7 ; 138 / 250)$ of the cases respectively.

\section{Magnetic resonance imaging}


Five studies $22,28,29,31,34$ (210 fetuses) reported the agreement between fetal MRI and postnatal or post-mortem assessment for the detection of the upper level of the lesion in fetuses with open spina bifida diagnosed prenatally. Overall, fetal MRI detected the exact level of the lesion in 42.5\% (95\% CI 35.9-45.2; 89/210) of cases; the level of the lesion recorded on MRI was higher in $26.4 \%$ (95\% CI 20.0-33.3; 43/165) and lower in $32.4 \%$ (95\% CI 25.5-39.7; 53/165) than that confirmed postnatally or at autopsy (Table 6).

The upper level of the lesion recorded on MRI was within one vertebral body in $76.2 \%$ (95\% CI 65.9-85.2; 162/207) of cases, while within two segments in 94.2\% (95\% CI 90.2-97.2; $164 / 173)$.

The discrepancy between the upper level of the lesion detected on ultrasound and that at postnatal assessment or autopsy was one vertebral body in $40.7 \%$ (95\% CI 33.5-40.8; 70/173) of cases, two in $13.4 \%$ (95\% CI 8.8-19.9; 22/73), three in 5.3\% (95\% CI 2.5-9.1; 8/173), while in none of the included cases there was a discrepancy of $\geq$ four vertebral bodies (Table 6).

\section{DISCUSSION}

The findings from this systematic review showed that ultrasound has a moderate diagnostic accuracy in correctly identifying the upper level of the lesion in fetuses with open spina bifida.

The agreement between ultrasound and postnatal or post-mortem was within one vertebral body in $76 \%$ and two vertebral bodies in $76 \%$ and within two in $92 \%$ of cases respectively. Although a direct comparison between the two techniques was not possible, the level of agreement between fetal MRI and postnatal assessment was similar to that reported on ultrasound. Finally, 3D ultrasound was associated with a higher rate of agreement compared to $2 \mathrm{D}$ ultrasound, although the small number of included cases limited the robustness of the analysis.

This is to our knowledge the first systematic review reporting the diagnostic accuracy of prenatal imaging in correctly identifying the level of the lesion in fetuses with open spina bifida. Thorough literature search and the multitude of outcomes explored represent the main strengths of the present systematic review. Small number of included studies, heterogeneity in gestational age at assessment, as well as the ultrasound technique and reference standard adopted for confirming the level of the lesion after birth or at post-mortem examination represent the main weakness of the present systematic review. Furthermore, the included studies did not differentiate between the anatomical and functional level of the lesion. Finally, the comparison between ultrasound and 
MRI was not reported in a blinded assessment in the original studies, thus making not possible to extrapolate a robust evidence on the actual role of MRI in prenatal assessment of fetuses with spina bifida.

It is widely known that the level of the lesion in spina bifida strongly influences the prognosis. According to the lesion level, the newborn can have difficulties in walking, sensory deficiency, motor deficiency and also incontinence problems, low school performance, and then in adulthood respiratory and cardiac problems. ${ }^{8,35-38}$ Children with lower level lesions are more likely to walk than those with higher level lesions. Moreover, the level and the extent of the defect are usually considered among the major predictors of the ability to walk, with quadriplegia often arising from cervical lesions and paraplegia mostly associated with thoracic and lumbosacral lesions. ${ }^{8,39-41}$

In view of this association, prenatal counselling of parents whose pregnancy is complicated by fetal spina bifida should explore the potential limitations of ultrasound in identifying the level of the lesion.

The findings from this meta-analysis showed that ultrasound has an overall moderate agreement in identifying the level of the lesion in fetuses with spina bifida aperta. Despite this, assessment of the level of the lesion on ultrasound has not been standardized yet and there is still large heterogeneity among different centers in the diagnostic criteria used to determine the level of the lesion, such as the most cephalic vertebra with evidence of laminar separation ${ }^{31}$ or the first vertebra showing widening of the ossification centers. ${ }^{30}$ Many authors also considered T12 as the insertion of the most caudal rib and the iliac crests as a landmark to locate L5 level. ${ }^{44}$ Identifying conus medullaris might be also helpful during spinal examination, as it usually ends at L4 level between 13 and 18 weeks and then tends to migrate, so it may often be recognized at L3 between 19 and 36 weeks and at L2 after 36 weeks of gestation..$^{42}$ The detection rate of spina bifida in second trimester routine ultrasound in nowadays very high, mostly because the examination of the spine has become mandatory and a longitudinal scan of the fetal spine should always also be obtained also during a basic assessment. ${ }^{43}$ Moreover, the development of 3D ultrasonography brought new possibilities to early diagnosis: 3D ultrasound allows to identify the whole spine and to examine images in sections and in different planes at the same time. Furthermore, in the past few years the use of antenatal MRI has significantly expanded in many fields of maternal and fetal medicine, ${ }^{11,44-45}$ but the most important role remains the evaluation of fetal nervous system: ${ }^{12,46}$ although in our study the level of agreement between prenatal imaging and postnatal assessment 
was similar for MRI and ultrasound. Fetal MRI is frequently performed as a secondary imaging tool to assess neural tube defects, rule out additional central nervous system (CNS) and non-CNS anomalies, and influence management decision. ${ }^{47}$

Finally, a proper identification of the topography of the lesion is also pivotal for preoperative assessment in case of intrauterine surgery. In fact, fetal therapy is offered only to fetuses affected by myelomeningocele with the upper boundary located between T1 and S1 and evidence of hindbrain herniation in the only randomized controlled trial (RCT) published so far comparing prenatal versus postnatal repair of the spina bifida. ${ }^{9}$ In this trial, prenatal surgery significantly reduced the need for cerebrospinal fluid shunt placement during the first year of life, improved psychomotor development at 30 months of age, and increased chances of independent ambulation at 30 months compared with those who underwent postnatal repair. ${ }^{9,48-50}$ However, the primary outcome of the study - the need for shunt placement - is subjective and open to the biases of the individual neurosurgeons caring for the infant.

Finally, prenatal procedure might be often complicated by preterm birth, oligohydramnios, spontaneous membrane rupture, placental abruption, pulmonary edema and higher incidence of uterine dehiscence of the hysterotomy site $^{9}$ and therefore minimally invasive strategies, such as fetoscopic approach, have been proposed to reduce open surgery risks, ${ }^{51}$ but further RCTs are needed to assess their real efficacy.

\section{CONCLUSION}

Ultrasound has an overall good accuracy in identifying the anatomical level of the lesion in fetuses with open spina bifida. The findings from this systematic review can improve prenatal counselling of parents whose pregnancy is complicated by open fetal spina bifida.

\section{REFERENCES}

1. Khoshnood B, Loane M, de Walle H et al. Long term trends in prevalence of neural tube defects in Europe: population based study. BMJ 2015; 351:h5949.

2. Ghi T, Pilu G, Falco P et al. Prenatal diagnosis of open and closed spina bifida. Ultrasound Obstet Gynecol 2006; 28:899-903. 
3. Maruotti GM, Saccone G, D'Antonio F et al. Diagnostic accuracy of intracranial translucency in detecting spina bifida: a systematic review and meta-analysis. Prenat Diagn 2016; 36:991-996.

4. Nicolaides KH, Campbell S, Gabbe SG, Guidetti R. Ultrasound screening for spina bifida: cranial and cerebellar signs. Lancet 1986; 2:72-74.

5. Bahlmann F, Reinhard I, Schramm T et al. Cranial and cerebral signs in the diagnosis of spina bifida between 18 and 22 weeks of gestation: a German multicentre study. Prenat Diagn 2015; 35:228-235.

6. Cameron M, Moran P. Prenatal screening and diagnosis of neural tube defects. Prenat Diagn 2009; 29:402-411.

7. Chaoui R, Benoit B, Mitkowska-Wozniak H, Heling KS, Nicolaides KH. Assessment of intracranial translucency (IT) in the detection of spina bifida at the 11-13-week scan. Ultrasound Obstet Gynecol 2009;34:249-252.

8. Adzick NS, Thom EA, Spong CY et al. A randomized trial of prenatal versus postnatal repair of myelomeningocele. N Engl J Med. 2011; 364:993-1004.

9. Pedreira DA, Zanon N, Nishikuni K, et al. Endoscopic surgery for the antenatal treatment of myelomeningocele: the CECAM trial. Am J Obstet Gynecol. 2016;214:111.e1-111.e11.

10. Di Mascio D, Sileo FG, Khalil A et al. Systematic review and meta-analysis on the role of prenatal magnetic resonance imaging in the era of fetal neurosonography: mild and moderate ventriculomegaly. Ultrasound Obstet Gynecol 2019; 54:164-171.

11. ENSO Working Group. Role of prenatal magnetic resonance imaging in fetuses with isolated mild or moderate ventriculomegaly in the era of neurosonography: international multicenter study. Ultrasound Obstet Gynecol. 2020; 56:340-347.

12. Lapa DA. Endoscopic fetal surgery for neural tube defects. Best Pract Res Clin Obstet Gynaecol. 2019;58:133-141.

13. Higgins JPT, Green, S.Cochrane Handbook for Systematic Reviews of Interventions. The Cochrane Collabouration; 2011. Available from: www.cochrane-handbook.org.

14. Moher D, Liberati A, Tetzlaff J, Altman DG; PRISMA Group. Preferred reporting items for systematic reviews and meta-analyses: the PRISMA statement. Ann Intern Med 2009; 151: $264-269$.

15. Zorzela L, Loke YK, Ioannidis JP et al. PRISMA harms checklist: improving harms reporting in systematic reviews. BMJ 2016; 352: i157. 
16. Newcastle-Ottawa Scale for assessing the quality of non randomised studies in metaanalyses. http://www.ohri.ca/programs/clinical_epidemiology/oxford.asp

17. Friedrich JO, Adhikari NK, Beyene J. Inclusion of zero total event trials in meta-analyses maintains analytic consistency and incorporates all available data. BMC Med Res Methodol. 2007; 7:5.

18. Sweeting MJ, Sutton AJ, Lambert PC. What to add to nothing? Use and avoidance of continuity corrections in meta-analysis of sparse data. Stat Med. 2004; 23:1351-1375.

19. Bradburn MJ, Deeks JJ, Berlin JA, Russell Localio A. Much ado about nothing: a comparison of the performance of meta-analytical methods with rare events. Stat Med. 2007; 26:53-77.

20. Newcombe RG. Two-sided confidence intervals for the single proportion: comparison of seven methods. Stat Med 1998; 17;857-72.

21. Sherrod BA, Ho WS, Hedlund A, Kennedy A, Ostrander B, Bollo RJ. A comparison of the accuracy of fetal MRI and prenatal ultrasonography at predicting lesion level and perinatal motor outcome in patients with myelomeningocele. Neurosurg Focus. 2019; 47:E4.

22. Nagaraj UD, Bierbrauer KS, Stevenson CB et al. Spinal Imaging Findings of Open Spinal Dysraphisms on Fetal and Postnatal MRI. AJNR Am J Neuroradiol. 2018; 39:1947-1952.

23. Requeijo MJ, Bunduki V, Francisco RP, Lopes MA, Ruano R, Zugaib M. Comparison of Two- and Three-dimensional Ultrasonography in the Evaluation of Lesion Level in Fetuses with Spina Bifida. Rev Bras Ginecol Obstet. 2016; 38:120-126.

24. Carreras E, Maroto A, Illescas T et al. Prenatal ultrasound evaluation of segmental level of neurological lesion in fetuses with myelomeningocele: development of a new technique. Ultrasound Obstet Gynecol. 2016; 47:162-167.

25. Buyukkurt S, Binokay F, Seydaoglu G et al. Prenatal determination of the upper lesion level of spina bifida with three-dimensional ultrasound. Fetal Diagn Ther. 2013; 33:36-40. 26. Aguilera S, Soothill P, Denbow M, Pople I. Prognosis of spina bifida in the era of prenatal diagnosis and termination of pregnancy. Fetal Diagn Ther. 2009; 26:68-74.

27. Van Der Vossen S, Pistorius LR, Mulder EJ et al. Role of prenatal ultrasound in predicting survival and mental and motor functioning in children with spina bifida. Ultrasound Obstet Gynecol. 2009; 34:253-258. 
28. Saleem SN, Said AH, Abdel-Raouf M et al. Fetal MRI in the evaluation of fetuses referred for sonographically suspected neural tube defects (NTDs): impact on diagnosis and management decision. Neuroradiology. 2009; 51:761-772.

29. Appasamy M, Roberts D, Pilling D, Buxton N. Antenatal ultrasound and magnetic resonance imaging in localizing the level of lesion in spina bifida and correlation with postnatal outcome. Ultrasound Obstet Gynecol. 2006; 27:530-536.

30. Bruner JP, Tulipan N, Dabrowiak ME et al. Upper level of the spina bifida defect: how good are we?. Ultrasound Obstet Gynecol. 2004; 24:612-617.

31. Aaronson OS, Hernanz-Schulman M, Bruner JP, Reed GW, Tulipan NB.

Myelomeningocele: prenatal evaluation--comparison between transabdominal US and MR imaging. Radiology. 2003; 227:839-843.

32. Lee W, Chaiworapongsa T, Romero R et al. A diagnostic approach for the evaluation of spina bifida by three-dimensional ultrasonography. J Ultrasound Med. 2002; 21:619-626.

33. Biggio JR Jr, Owen J, Wenstrom KD, Oakes WJ. Can prenatal ultrasound findings predict ambulatory status in fetuses with open spina bifida? Am J Obstet Gynecol. 2001;

185:1016-1020.

34. Mangels KJ, Tulipan N, Tsao LY, Alarcon J, Bruner JP. Fetal MRI in the evaluation of intrauterine myelomeningocele. Pediatr Neurosurg. 2000; 32:124-131.

35. Bowman RM, McLone DG, Grant JA, Tomita T, Ito JA. Spina bifida outcome: a 25-year prospective. Pediatr Neurosurg. 2001; 34:114-120.

36. Matson MA, Mahone EM, Zabel TA. Serial neuropsychological assessment and evidence of shunt malfunction in spina bifida: a longitudinal case study. Child Neuropsychol. 2005; 11:315-332.

37. Müller T, Arbeiter K, Aufricht C. Renal function in meningomyelocele: risk factors, chronic renal failure, renal replacement therapy and transplantation. Curr Opin Urol. 2002; 12:479-484.

38. Smith K, Neville-Jan A, Freeman KA et al. The effectiveness of bowel and bladder interventions in children with spina bifida. Dev Med Child Neurol. 2016; 58:979-988.

39. Main DM, Mennuti MT. Neural tube defects: issues in prenatal diagnosis and counselling. Obstet Gynecol. 1986; 67:1-16.

40. Roach JW, Short BF, Saltzman HM. Adult consequences of spina bifida: a cohort study. Clin Orthop Relat Res. 2011; 469:1246-1252. 
41. Dicianno BE, Sherman A, Roehmer C, Zigler CK. Co-morbidities Associated With Early Mortality in Adults With Spina Bifida. Am J Phys Med Rehabil. 2018; 97:861-865.

42. Coleman BG, Langer JE, Horii SC. The diagnostic features of spina bifida: the role of ultrasound. Fetal Diagn Ther. 2015; 37:179-196.

43. International Society of Ultrasound in Obstetrics \& Gynecology Education Committee. Sonographic examination of the fetal central nervous system: guidelines for performing the 'basic examination' and the 'fetal neurosonogram'. Ultrasound Obstet Gynecol. 2007; 29:109-116.

44. Di Mascio D, Buca D, Khalil A et al. Outcome of isolated fetal talipes: A systematic review and meta-analysis. Acta Obstet Gynecol Scand. 2019; 98:1367-1377.

45. Di Mascio D, Calì G, D'antonio F. Updates on the management of placenta accreta spectrum. Minerva Ginecol. 2019; 71:113-120.

46. Rossi AC, Prefumo F. Additional value of fetal magnetic resonance imaging in the prenatal diagnosis of central nervous system anomalies: a systematic review of the literature. Ultrasound Obstet Gynecol. 2014; 44:388-393.

47. Saleem SN, Said AH, Abdel-Raouf M et al. Fetal MRI in the evaluation of fetuses referred for sonographically suspected neural tube defects (NTDs): impact on diagnosis and management decision. Neuroradiology. 2009; 51:761-772.

48. Brock JW 3rd, Carr MC, Adzick NS et al. Bladder Function After Fetal Surgery for Myelomeningocele. Pediatrics 2015; 136:e906-913.

49. Tulipan N, Wellons JC 3rd, Thom EA et al. Prenatal surgery for myelomeningocele and the need for cerebrospinal fluid shunt placement. J Neurosurg Pediatr 2015; 16:613-620.

50. Farmer DL, Thom EA, Brock JW 3rd et al. The Management of Myelomeningocele Study: full cohort 30-month pediatric outcomes. Am J Obstet Gynecol 2018; 218:256.e1-13.

51. Lapa Pedreira DA, Acacio GL, Gonçalves RT et al. Percutaneous fetoscopic closure of large open spina bifida using a bilaminar skin substitute. Ultrasound Obstet Gynecol. 2018; 52:458-466.

\section{Legend}

This article is protected by copyright. All rights reserved 
Figure 1. Prisma flow diagram.

\section{Supporting Information legends}

Table S1. Excluded studies and reason for the exclusion.

Table S2. Methods to determine the level of the lesion at ultrasound. 
Table 1. General Characteristics of the included studies.

\begin{tabular}{|c|c|c|c|c|c|c|c|c|}
\hline Author & Year & Country & Study design & $\begin{array}{l}\text { Period } \\
\text { considered }\end{array}$ & $\begin{array}{l}\text { Gestational age } \\
\text { at assessment } \\
\text { (weeks) }\end{array}$ & $\begin{array}{l}\text { Prenatal } \\
\text { imaging }\end{array}$ & $\begin{array}{l}\text { Reference } \\
\text { standard }\end{array}$ & $\begin{array}{l}\text { Cases } \\
\text { (n) }\end{array}$ \\
\hline Sherrod $^{20}$ & 2019 & United States & Retrospective & $2013-2018$ & $\begin{array}{l}23.0 \pm 4.7(\mathrm{US}) \\
24.0 \pm 4.1(\mathrm{MRI})\end{array}$ & US, MRI & Surgery & 34 \\
\hline Nagaraj $^{21}$ & 2018 & United States & Retrospective & $2004-2016$ & $23.9+/-3.6 \mathrm{w}$ & MRI & MRI & 119 \\
\hline Requeijo $^{22}$ & 2016 & Brazil & Prospective & $2004-2013$ & $27.1(18-38) \mathrm{w}$ & 2D-3D US & X-ray & 50 \\
\hline Carreras $^{23}$ & 2016 & Spain & Observational & $2011-2015$ & $18-26$ & $2 \mathrm{D}$ & Surgery & 18 \\
\hline${\text { Buyukkurt }{ }^{24}}^{24}$ & 2012 & Turkey & Prospective & $2010-2011$ & $25+/-7.1(16-39)$ & 3D-US & $\begin{array}{l}\text { X- } \\
\text { ray, autops } \\
\text { y }\end{array}$ & 48 \\
\hline Aguilera $^{25}$ & 2009 & $\begin{array}{l}\text { United } \\
\text { Kingdom }\end{array}$ & Retrospective & 1999-2007 & $20(16-37)$ & 2D-US & $\begin{array}{l}\text { MRI, X- } \\
\text { ray }\end{array}$ & 18 \\
\hline $\begin{array}{l}\text { Van Der } \\
\text { Vossen }^{26}\end{array}$ & 2009 & $\begin{array}{l}\text { The } \\
\text { Netherlands }\end{array}$ & Retrospective & $1997-2007$ & $27.5(18-42)$ & 2D US & MRI & 58 \\
\hline Saleem $^{27}$ & 2009 & Egypt & Retrospective & $2006-2008$ & $23(19-39)$ & $\begin{array}{l}\text { 2D-3D US, } \\
\text { MRI }\end{array}$ & $\begin{array}{l}\text { MRI, X- } \\
\text { ray }\end{array}$ & 8 \\
\hline Appasamy $^{28}$ & 2006 & $\begin{array}{l}\text { United } \\
\text { Kingdom }\end{array}$ & Retrospective & $2000-2002$ & $20.2(16-23)$ & $\begin{array}{l}\text { 2D US, } \\
\text { MRI }\end{array}$ & $\begin{array}{l}\text { MRI, } \\
\text { suregry }\end{array}$ & 12 \\
\hline Bruner $^{29}$ & 2004 & USA & Retrospective & $1997-2003$ & $23(17+6$ to $28+6)$ & 2D US & $\begin{array}{l}\text { X-ray, } \\
\text { MRI }\end{array}$ & 111 \\
\hline Aaronson $^{30}$ & 2003 & United States & Prospective & $1997-2002$ & $21-29$ & US, MRI & $\begin{array}{l}\text { MRI, X- } \\
\text { ray }\end{array}$ & 100 \\
\hline $\mathrm{Lee}^{31}$ & 2002 & United States & Retrospective & NS & $\begin{array}{l}21.8 \mathrm{w} \pm \\
3.4(2 \mathrm{DUS}), 22.8 \\
\pm 4.4(3 \mathrm{D} \text { US })\end{array}$ & 2D-3D US & $\begin{array}{l}\text { MRI, X- } \\
\text { ray }\end{array}$ & 9 \\
\hline Biggio $^{32}$ & 2001 & $\begin{array}{l}\text { United } \\
\text { Kingdom }\end{array}$ & Retrospective & $1996-2000$ & $21 \pm 4.9$ & 2D US & $\begin{array}{l}\text { X-ray, } \\
\text { surgery }\end{array}$ & 33 \\
\hline Mangels $^{33}$ & 2000 & United States & Retrospective & NS & 19.5-27.4 (range) & MRI & MRI & 37 \\
\hline
\end{tabular}

$\mathrm{N}$, numbers; US, ultrasound; MRI, magnetic resonance imaging, NS, not specified.

This article is protected by copyright. All rights reserved 
Table 2. Quality assessment of the included studies according to Newcastle-Ottawa Scale (NOS) for cohort studies; a study can be awarded a maximum of one star for each numbered item within the Selection and Outcome categories. A maximum of two stars can be given for Comparability.

\begin{tabular}{|c|c|c|c|c|}
\hline Author & Year & Selection & Comparability & Outcome \\
\hline Sherrod $^{20}$ & 2019 & $\star \star \star$ & $\star$ & $\star \star$ \\
\hline Nagaraj $^{21}$ & 2018 & $\star \star \star$ & $\star$ & $\star \star$ \\
\hline Requeijo $^{22}$ & 2016 & $\star \star \star$ & $\star$ & $\star \star$ \\
\hline Carreras $^{23}$ & 2016 & $\star \star \star$ & $\star$ & $\star \star$ \\
\hline Buyukkurt $^{24}$ & 2012 & $\star \star \star$ & $\star$ & $\star \star$ \\
\hline Aguilera $^{25}$ & 2009 & $\star \star \star$ & $\star$ & $\star \star$ \\
\hline $\begin{array}{l}\text { Van Der } \\
\text { Vossen }^{26}\end{array}$ & 2009 & $\star \star \star$ & $\star$ & $\star \star$ \\
\hline Saleem $^{27}$ & 2009 & $\star \star \star$ & $\star$ & $\star \star$ \\
\hline Appasamy ${ }^{28}$ & 2006 & $\star \star \star$ & $\star$ & $\star \star$ \\
\hline Bruner $^{29}$ & 2004 & $\star \star \star$ & $\star$ & $\star \star$ \\
\hline Aaronson $^{30}$ & 2003 & $\star \star \star$ & $\star$ & $\star \star$ \\
\hline $\mathrm{Lee}^{31}$ & 2002 & $\star \star \star$ & $\star$ & $\star \star$ \\
\hline Biggio $^{32}$ & 2001 & $\star \star \star$ & $\star$ & $\star \star$ \\
\hline Mangels $^{33}$ & 2000 & $\star \star \star$ & $\star$ & $\star \star$ \\
\hline
\end{tabular}


Table 3. Pooled proportions ( $95 \%$ CI) showing the rate of agreement between ultrasound (either 2D or 3D) and postnatal or postmortem assessment.

\begin{tabular}{|c|c|c|c|c|c|c|}
\hline ( & $\begin{array}{l}\text { Studies } \\
\text { (n) }\end{array}$ & References & $\begin{array}{l}\text { Fetuses } \\
\text { (n) }\end{array}$ & $\begin{array}{l}\text { Raw proportions } \\
(95 \% \mathrm{CI})\end{array}$ & $\mathbf{I}^{2}$ & $\begin{array}{l}\text { Pooled proportions } \\
(95 \% \text { CI) }\end{array}$ \\
\hline Same level than post-natal & 10 & $22-31$ & $193 / 452$ & $42.70(38.1-47.4)$ & 88.8 & $40.86(26.9-55.6)$ \\
\hline US higher than post-natal & 7 & $23-26,28,30-31$ & $57 / 233$ & $24.46(19.1-30.5)$ & 92.4 & $31.71(11.9-55.8)$ \\
\hline US lower than post-natal & 7 & $23-26,28,30-31$ & $81 / 233$ & $34.76(28.7-41.3)$ & 88.6 & $25.71(10.5-44.8)$ \\
\hline Within one level & 10 & $20,22-24,26-31$ & $359 / 468$ & $76.71(72.6-80.5)$ & 84.5 & $76.24(65.0-85.9)$ \\
\hline Within two levels & 9 & $22-24,26-31$ & $397 / 434$ & $91.47(88.4-93.9)$ & 83.7 & $92.38(84.3-97.7)$ \\
\hline$T$ & & & & & & \\
\hline One level than post-natal & 9 & $22-24,26-31$ & $155 / 434$ & $35.71(31.2-40.4)$ & 72.3 & $34.28(25.2-43.9)$ \\
\hline One level higher than post-natal & 7 & $22-24,26,28,30-31$ & $48 / 315$ & $15.24811 .5-19.7)$ & 53.3 & $16.10(10.2-23.1)$ \\
\hline One level lower than post-natal & 7 & $22-24,26,28,30-31$ & $57 / 315$ & $18.10(14.0-22.8)$ & 72.8 & $17.45(13.5-21.8)$ \\
\hline Two levels than post-natal & 9 & $22-24,26-31$ & $90 / 467$ & $19.27(15.8-23.1)$ & 92.9 & $20.49(8.2-36.6)$ \\
\hline $\begin{array}{l}\text { Two levels higher than post- } \\
\text { natal }\end{array}$ & 6 & $23-24,26,28,30-31$ & $10 / 215$ & $4.65(2.3-8.4)$ & 71.2 & $5.88(1.2-13.8)$ \\
\hline two levels lower than post-natal & 6 & $23-24,26,28,30-31$ & $22 / 215$ & $10.23(6.5-15.1)$ & 76.0 & $8.54(2.2-18.5)$ \\
\hline Three levels than post-natal & 9 & $22-2426-3$ & $22 / 467$ & $471(30-70)$ & 702 & $431,(14877$ \\
\hline $\begin{array}{l}\text { Three levels higher than post- } \\
\text { natal }\end{array}$ & 6 & $23-24,26,28,30-31$ & $3 / 215$ & $1.40(0.3-4.0)$ & 23.1 & $1.72(0.3-4.4)$ \\
\hline $\begin{array}{l}\text { Three levels lower than post- } \\
\text { natal }\end{array}$ & 6 & $23-24,26,28,30-31$ & $5 / 215$ & $2.33(0.8-5.3)$ & 1.6 & $2.61(0.9-5.2)$ \\
\hline 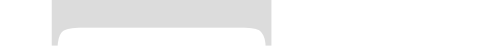 & & & & & & \\
\hline $\begin{array}{l}\text { Four or more levels than post- } \\
\text { natal }\end{array}$ & 9 & $22-24,26-31$ & $12 / 467$ & $2.57(1.3-4.4)$ & 73.7 & $2.40(0.03-6.2)$ \\
\hline $\begin{array}{l}\text { Four or more levels higher than } \\
\text { post-natal }\end{array}$ & 6 & $23-24,26,28,30-31$ & $5 / 215$ & $2.33(0.8-5.3)$ & 61.0 & $2.68(0.2-7.7)$ \\
\hline $\begin{array}{l}\text { Four or more levels lower than } \\
\text { post-natal }\end{array}$ & 6 & $23-24,26,28,30-31$ & $7 / 215$ & $3.26(1.3-6.6)$ & 65.0 & $2.38(0.01-7.5)$ \\
\hline
\end{tabular}

This article is protected by copyright. All rights reserved 
Table 4. Pooled proportions (95\% CI) showing the rate of agreement between $2 \mathrm{D}$ ultrasound and postnatal or postmortem assessment.

\begin{tabular}{|c|c|c|c|c|c|c|}
\hline$\infty$ & $\begin{array}{l}\text { Studies } \\
\text { (n) }\end{array}$ & References & $\begin{array}{l}\text { Fetuses } \\
\text { (n) }\end{array}$ & $\begin{array}{l}\text { Raw proportions } \\
(95 \% \text { CI })\end{array}$ & $\mathbf{I}^{2}$ & $\begin{array}{l}\text { Pooled proportions } \\
(95 \% \text { CI })\end{array}$ \\
\hline Same level than post-natal & 9 & $22-23,25-31$ & $155 / 404$ & $38.37(33.6-43.3)$ & 83.3 & $36.01(24.0-49.0)$ \\
\hline US higher than post-natal & 6 & $\begin{array}{l}23,25-26,28,30- \\
31\end{array}$ & $52 / 185$ & $28.11(21.9-35.3)$ & 93 & $36.15(12.0-64.9)$ \\
\hline US lower than post-natal & 6 & $\begin{array}{l}23,25-26,28,30- \\
31\end{array}$ & $76 / 185$ & $41.08(34.0-48.5)$ & 85.7 & $29.02(12.5-49.0)$ \\
\hline Within one level & 9 & $20,22-23,26-31$ & $311 / 420$ & $74.05(69.5-78.1)$ & 61.4 & $71.83(63.8-79.2)$ \\
\hline Within two levels & 8 & $22-23,26-31$ & $349 / 386$ & $90.41(86.9-93.1)$ & 82.9 & $90.72(81.6-97.0)$ \\
\hline $1-1$ & & & & & & \\
\hline One level than post-natal & 8 & $22-23,26-31$ & $145 / 386$ & $37.56(32.7-42.6)$ & 70.4 & $36.38(26.8-46.6)$ \\
\hline One level higher than post-natal & 6 & $\begin{array}{l}22-23,26,28,30- \\
31\end{array}$ & $43 / 267$ & $16.1(12.0-21.2)$ & 58.5 & $17.33(10.2-25.9)$ \\
\hline One level lower than post-natal & 6 & $\begin{array}{l}22-23,26,28,30- \\
31\end{array}$ & $52 / 267$ & $19.48(15.0-24.8)$ & 75.3 & $15.36 / 7.0-26.2)$ \\
\hline Two levels than post-natal & 9 & $22-23,26-32$ & $90 / 419$ & $21.48(17.7-25-8)$ & 91.8 & $24.45(11.0-41.3)$ \\
\hline Two levels higher than post-natal & 5 & $23,26,28,30-31$ & $10 / 167$ & $5.99(3.1-11.0)$ & 69.9 & $8.14(1.8-18.5)$ \\
\hline two levels lower than post-natal & 5 & $23,26,28,30-31$ & $22 / 167$ & $13.17(8.6-19.5)$ & 44.7 & $12.23(5.9-20.5)$ \\
\hline Three levels than post-natal & 9 & $22-23,26-32$ & $22 / 419$ & $5.25(3.4-8.0)$ & 70.0 & $5.08(1.7-10.2)$ \\
\hline Three levels higher than post-natal & 5 & $23,26,28,30-31$ & $3 / 167$ & $1.8(0.5-5.6)$ & 31.2 & $2.34(0.3-6.3)$ \\
\hline Three levels lower than post-natal & 5 & $23,26,28,30-31$ & $5 / 167$ & $2.99(1.1-7.2)$ & 0 & $3.50(1.3-6.8)$ \\
\hline Four or more levels than post-natal & 9 & $22-23,26-32$ & $12 / 419$ & $2.86(1.6-5.1)$ & 76.2 & $2.79(0.6-5.2)$ \\
\hline $\begin{array}{l}\text { Four or more levels higher than } \\
\text { post-natal }\end{array}$ & 5 & $23,26,28,30-31$ & $5 / 167$ & $2.99(1.1-7.2)$ & 66.1 & $2.35(0.2-11.0)$ \\
\hline $\begin{array}{l}\text { Four or more levels lower than } \\
\text { post-natal }\end{array}$ & 5 & $23,26,28,30-31$ & $7 / 167$ & $4.19(1.8-8.8)$ & 67.9 & $3.04(0.1-10.2)$ \\
\hline
\end{tabular}

This article is protected by copyright. All rights reserved 
Table 5. Pooled proportions (95\% CI) showing the rate of agreement between 3D ultrasound and postnatal or postmortem assessment.

\begin{tabular}{|c|c|c|c|c|c|c|}
\hline ) & $\begin{array}{l}\text { Studies } \\
\text { (n) }\end{array}$ & References & Fetuses (n) & $\begin{array}{l}\text { Raw proportions } \\
(95 \% \mathrm{CI})\end{array}$ & $I^{2}$ & $\begin{array}{l}\text { Pooled proportions } \\
(95 \% \text { CI })\end{array}$ \\
\hline Same level than post-natal & 3 & $22,24,31$ & $95 / 157$ & $60.5(52.4-68.1)$ & 84.7 & $67.14(43.7-86.7)$ \\
\hline US higher than post-natal & 2 & 24,31 & $6 / 57$ & $3.82(1.6-8.5)$ & 0 & $11.71(4.8-21.2)$ \\
\hline US lower than post-natal & 2 & 24,31 & $6 / 57$ & $3.82(1.6-8.5)$ & 0 & $11.71(4.8-21.2)$ \\
\hline Within one level & 3 & $22,24,31$ & $139 / 157$ & $88.54(82.2-92.9)$ & 89.4 & $94.59(75.4-99.8)$ \\
\hline Within two levels & 3 & $22,24,31$ & $147 / 157$ & $93.63(88.3-96.7)$ & 77.4 & $96.17(85.3-99.9)$ \\
\hline One level than post-natal & 3 & $22,24,31$ & $44 / 157$ & $28.03(21.3-35.8)$ & 0.5 & $28.28(21.5-35.6)$ \\
\hline $\begin{array}{l}\text { One level higher than post- } \\
\text { natal }\end{array}$ & 3 & $22,24,31$ & $18 / 157$ & $11.46(7.1-17.8)$ & 0 & $12.14(7.5-17.7)$ \\
\hline $\begin{array}{l}\text { One level lower than post- } \\
\text { natal }\end{array}$ & 3 & $22,24,31$ & $26 / 157$ & $16.56(11.3-23.5)$ & 5.6 & $16.80(11.1-23.4)$ \\
\hline Two levels than post-natal & 3 & $22,24,31$ & $8 / 157$ & $5.10(2.4-10.1)$ & 69.8 & $3.40(0.001-12.1)$ \\
\hline $\begin{array}{l}\text { Two levels higher than post- } \\
\text { natal }\end{array}$ & - & & - & - & - & - \\
\hline $\begin{array}{l}\text { two levels lower than post- } \\
\text { natal }\end{array}$ & - & & - & - & - & \\
\hline & & & & & & \\
\hline $\begin{array}{l}\text { Three levels than post- } \\
\text { natal }\end{array}$ & 3 & $22,24,31$ & $10 / 157$ & $6.37(3.3-11.7)$ & 77.4 & $3.83(6.3-14.7)$ \\
\hline $\begin{array}{l}\text { Three levels higher than } \\
\text { post-natal }\end{array}$ & - & & - & - & - & - \\
\hline $\begin{array}{l}\text { Three levels lower than } \\
\text { post-natal }\end{array}$ & - & & - & - & - & - \\
\hline Four or more levels than & 3 & $22,24,31$ & $0 / 157$ & $0(0-3.0)$ & 0 & $0(0-2.0)$ \\
\hline
\end{tabular}

This article is protected by copyright. All rights reserved 


\begin{tabular}{|l|l|l|l|l|l|l|} 
post-natal & & & & & \\
\hline $\begin{array}{l}\text { Four or more levels higher } \\
\text { than post-natal }\end{array}$ & 3 & $22,24,31$ & $0 / 157$ & $0(0-3.0)$ & 0 & $0(0-2.0)$ \\
\hline $\begin{array}{l}\text { Four or more levels lower } \\
\text { than post-natal }\end{array}$ & 3 & $22,24,31$ & $0 / 157$ & $0(0-3.0)$ & 0 & $0(0-2.0)$ \\
\hline
\end{tabular}

This article is protected by copyright. All rights reserved 
Table 6. Pooled proportions $(95 \% \mathrm{CI})$ showing the rate of agreement between fetal magnetic resonance imaging (MRI) and postnatal or postmortem assessment.

\begin{tabular}{|c|c|c|c|c|c|c|}
\hline (2) & $\begin{array}{l}\text { Studies } \\
\text { (n) }\end{array}$ & References & Fetuses (n) & $\begin{array}{l}\text { Raw proportions } \\
(95 \% \mathrm{CI})\end{array}$ & $\mathbf{I}^{2}$ & $\begin{array}{l}\text { Pooled } \\
\text { proportions }(95 \% \\
\text { CI) }\end{array}$ \\
\hline Same level than post-natal & 5 & $21,27,28,30,33$ & $89 / 210$ & $42.38(35.6-49.4)$ & 0 & $42.50(35.9-49.2)$ \\
\hline MRI higher than post-natal & 3 & $21,28,30$ & $43 / 165$ & $26.06(19.5-33.5)$ & 0 & $26.41(20.0-33.3)$ \\
\hline MRI lower than post-natal & 3 & $21,28,30$ & $53 / 165$ & $32.12(25.1-39.8)$ & 0 & $32.37(25.5-39.7)$ \\
\hline & & & & & & \\
\hline Within one level & 5 & $20.21,27,28,30$ & $162 / 207$ & $78.26(72.0-83.7)$ & 49.4 & $76.21(65.9-85.2)$ \\
\hline Within two levels & 4 & $21,27,28,30$ & $164 / 173$ & $94.80(90.4-97.6)$ & 0 & $94.18(90.2-97.2)$ \\
\hline$r$ & & & & & & \\
\hline One level than post-natal & 4 & $21,27,28,30$ & $70 / 173$ & $40.46(33.1-48.2)$ & 0 & $40.65(33.5-48.0)$ \\
\hline $\begin{array}{l}\text { One level higher than post- } \\
\text { natal }\end{array}$ & 2 & 28,30 & $11 / 46$ & $23.91(12.6-38.8)$ & 0 & $24.85(13.7-38.1)$ \\
\hline $\begin{array}{l}\text { One level lower than post- } \\
\text { natal }\end{array}$ & 2 & 28,30 & $9 / 46$ & $19.57(9.4-33.9)$ & 0 & $20.74(10.5-33.4)$ \\
\hline . & & & & & & \\
\hline Two levels than post-natal & 4 & $21,27,28,30$ & $22 / 173$ & $12.72(8.1-18.6)$ & 0 & $13.43(8.8-19.9)$ \\
\hline $\begin{array}{l}\text { Two levels higher than post- } \\
\text { natal }\end{array}$ & 2 & 28,30 & $3 / 46$ & $6.52(1.4-17.9)$ & 0 & $7.84(2.0-17.1)$ \\
\hline $\begin{array}{l}\text { two levels lower than post- } \\
\text { natal }\end{array}$ & 2 & 28,30 & $4 / 46$ & $8.70(2.4-20.8)$ & 0 & $9.55(2.9-19.5)$ \\
\hline Three levels than post-natal & 4 & $21,27,28,30$ & $8 / 173$ & $4.62(2.0-8.9)$ & 0 & $5.28(2.5-9.1)$ \\
\hline $\begin{array}{l}\text { Three levels higher than post- } \\
\text { natal }\end{array}$ & 2 & 28,30 & $0 / 46$ & $0(0-7.1)$ & 0 & $0(0-5.6)$ \\
\hline $\begin{array}{l}\text { Three levels lower than post- } \\
\text { natal }\end{array}$ & 2 & 28,30 & $1 / 46$ & $2.17(0.01-11.5)$ & 0 & $3.57(0.2-10.7)$ \\
\hline $\begin{array}{l}\text { Four or more levels than post- } \\
\text { natal }\end{array}$ & 4 & $21,27,28,30$ & $0 / 173$ & $0(0-2.1)$ & 0 & $0(0-19.3)$ \\
\hline $\begin{array}{l}\text { Four or more levels higher } \\
\text { than post-natal }\end{array}$ & 2 & 28,30 & $0 / 46$ & $0(0-7.1)$ & 0 & $0(0-5.6)$ \\
\hline $\begin{array}{l}\text { Four or more levels lower } \\
\text { than post-natal }\end{array}$ & 2 & 28,30 & $0 / 46$ & $0(0-7.1)$ & 0 & $0(0-5.6)$ \\
\hline
\end{tabular}

This article is protected by copyright. All rights reserved 


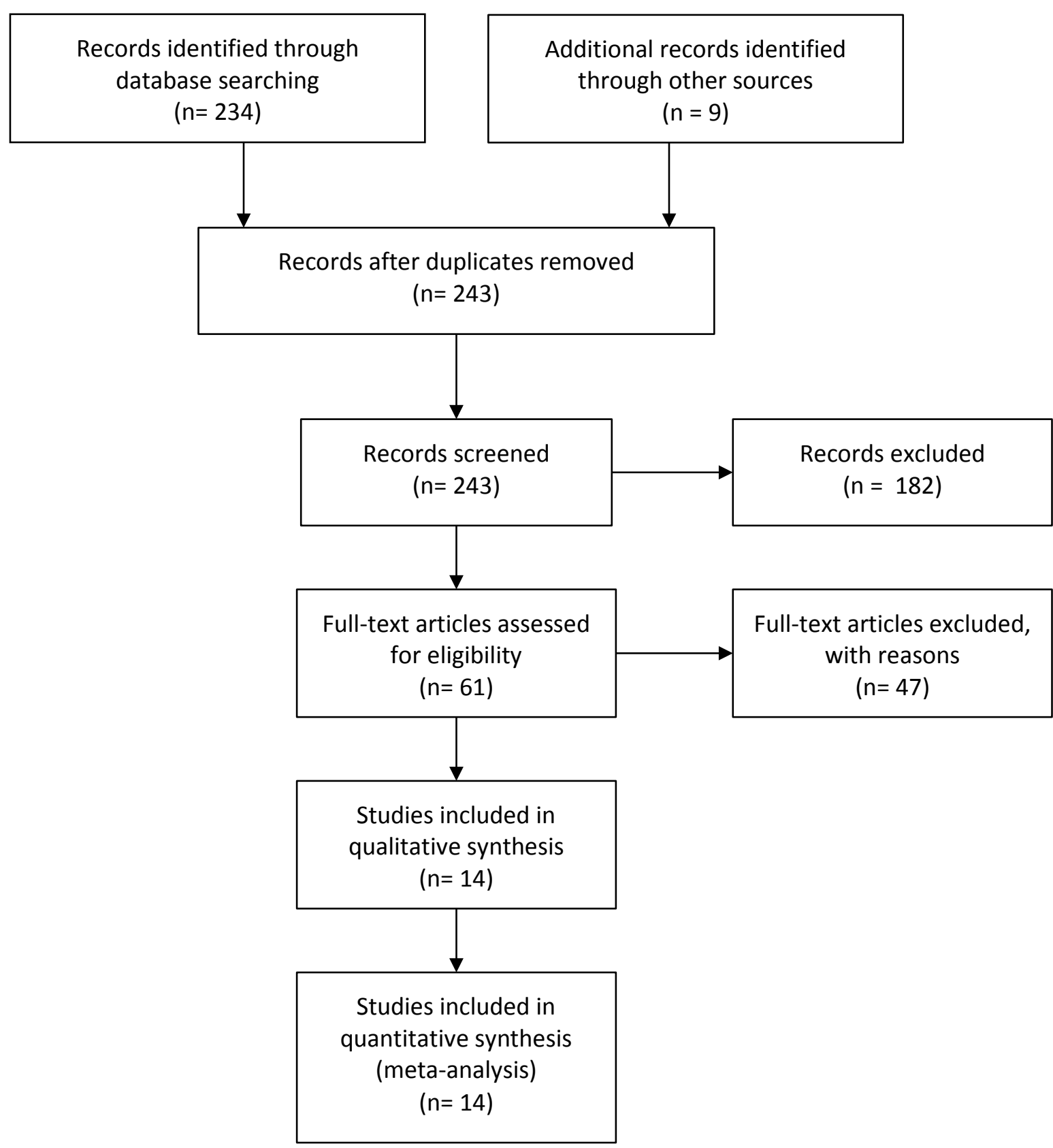

From: Moher D, Liberati A, Tetzlaff J, Altman DG, The PRISMA Group (2009). Preferred Reporting Items for Systematic Reviews and MetaAnalyses: The PRISMA Statement. PLoS Med 6(6): e1000097. doi:10.1371/journal.pmed1000097 